\title{
Political parties matter: a research agenda on interactions among elites in post-conflict democracies
}

\section{Giampiero Cama \& Fabrizio Coticchia}

To cite this article: Giampiero Cama \& Fabrizio Coticchia (2018): Political parties matter: a research agenda on interactions among elites in post-conflict democracies, Contemporary Politics, DOI: $10.1080 / 13569775.2018 .1552236$

To link to this article: https://doi.org/10.1080/13569775.2018.1552236

曲 Published online: 30 Nov 2018.

Submit your article to this journal $\widetilde{ }$

山 Article views: 4

View Crossmark data $\complement$ 


\title{
Political parties matter: a research agenda on interactions among elites in post-conflict democracies
}

\author{
Giampiero Cama and Fabrizio Coticchia \\ Department of Political Science, University of Genoa, Genoa, Italy
}

\begin{abstract}
The literature has devoted considerable attention to the understanding of state institutions and rule of law in the processes of democratization. However, despite the crucial relevance of dynamic and repeated interactions between actors and institutions in non-homogenous post-conflict societies, most research lacks systematic analyses on the role of parliaments, parties and party systems after civil wars. While several studies have examined the effects of electoral systems or veto rights after power-sharing agreements, as well as the transformation of rebel groups into political parties in post-conflict societies, the development of parties within parliaments has been largely ignored. Therefore, by combining conflict studies, institutional design perspectives and peacebuilding approaches, this paper presents a research agenda on the overlooked role played by parliament as a crucial arena for a better analysis, in the long term, of power-sharing mechanisms and state-building, post-war political framing and narratives, ethnic outbidding and party modernization strategies.
\end{abstract}

\author{
Keywords \\ Peacebuilding; institutions; \\ conflicts; parties; party \\ systems; parliaments
}

\section{Introduction}

A crisis of what is called 'liberal peace' has recently emerged as a result of a growing array of problems and failures. The operations in Iraq and Afghanistan have illustrated the setbacks of international liberal peacebuilding (Newmann, Paris, \& Richmond, 2009). Other approaches, such as 'hybrid peace' or 'resilience', have radically questioned the main topdown assumptions of Western humanitarian interventions (Chandler, 2004; Mac Ginty, 2010). At the same time, comparative politics literature has devoted considerable attention to the understanding of state institutions and rule of law in the processes of democratization.

The literature has clarified how political institutions can effectively mitigate conflicts, fostering inclusion and creating a pattern of behaviours around which expectations converge (Hartzell, 1999). Local institutions can bring down conflicts between communities while accommodation can soften the incompatibility of interests. The need has gradually emerged among scholars to focus on the implementation of peace agreements as well as on the dynamic interactions between actors, political institutions and exogenous factors in non-homogenous post-conflict societies (Spears, 2000). However, the 
'compartmentalization' of current research on civil wars, conflict management, democratization and peacebuilding hinders the development of systematic analyses on the dialectic relation between conflicts and domestic institutions.

Recent analyses (Hensell \& Gerdes, 2012; Grimm \& Weiffen, 2018; Groß, 2018; Zürcher, 2018) in peacebuilding and democracy promotion have examined the relationship between domestic elites and international actors, stressing the need to 'disentangle such complex interaction process' (Groß, 2018, p. 304), looking at different goals and preferences. Despite such attempts, 'insights into the nature and dynamics of this interaction remain scarce' (Bunk, 2018, p. 323). A detailed investigation is especially required to understand the strategic bargaining between domestic actors, whose role has been 'overlooked' by current debate (Grimm \& Weiffen, 2018, p. 258). Among domestic players in post-conflict societies, the literature has devoted little attention to the repeated interactions between political parties in legislative contexts as well as to the features and the institutionalization of parties, which aggregate and express political demands. ${ }^{1}$

Rather than examining the relationship between domestic elites and international actors, the main focus of this paper is the parliamentary interaction between political parties in post-conflict societies. There are several studies that have examined the effects of electoral systems, veto rights or reserved seats after power-sharing agreements, as well as the transformation of rebel groups into political parties in post-conflict societies.

Yet, despite some exceptions (Ishiyama, 2014; Reilly \& Nordlund, 2008), there are few studies concerning party development after elections, especially within the more typical institutional context - the parliament - in which parties operate. Even though political institutions are generally perceived as crucial for addressing exclusion and state fragility, and notwithstanding the mounting interest on the implementation of peace agreements and powersharing, how parties develop their political activities in parliament has received 'little attention' (Kumar \& de Zeeuw, 2008, p. 276). As stressed by Ishiyama (2014, pp. 425-426), there is still 'very little literature that addresses the evolution of party politics after civil wars'. In line with Alfieri (2016, p. 234), scholars also 'underestimate' the importance of studying parties in post-conflict in non-Western regions, such as Africa. Despite the increasing interest devoted by civil war research to framing the grievances among the main political players, as well as to emotions and ideologies, few studies ${ }^{2}$ have been conducted on the role of political parties in crafting narratives and frames in post-conflict situations.

Furthermore, notwithstanding growing consideration to ethnic outbidding, 'de-nationalizing politics', and 'party modernization' in peace process ${ }^{3}$, there aren't systematic (and cross-time) analyses of (local and national) parliamentary debates, which would allow a detailed examination of the integration of elites and strategies of pragmatism, cooperation and/or 'ethnic tribune appeals' in post-conflict societies (Moore, Loizides, Sandal, \& Lordos, 2014).

In short, the relationship between parties should be 'more fully explored' (Manning and Smith 2018, p. 26). This paper aims at addressing such need, developing a research agenda on parties in post-conflict parliaments, stressing the elements that deserve greater interest, and advancing plausible hypotheses that can be tested in further studies.

The contribution of the paper to the current debate is threefold. First, we critically revise the scholarly discussion on conflicts and institutions, advancing a typology that connects different branches of the literature, allowing focusing on the underrated role played by 
parties in post-war assemblies. Second, the paper identifies the main paths - as well the most significant gaps - of the existing analyses on political parties in post-conflict societies. Third, through selected empirical examples, the manuscript provides a potential research agenda, advancing plausible hypothesis on political parties in post-conflict societies.

This paper proceeds as follows. After having illustrated the current debate on powersharing, conflicts and institutions, the dynamic interactions between actors are presented as the most relevant aspect that deserves investigation by the literature. Hence, the paper focuses on parties in post-conflict divided societies and, through empirical examples, advances three arguments of a research agenda on parties within post-civil war parliaments: the intergroup party dynamics in legislative arenas, the symbolic dimension and methodological and normative unsolved problems in party development studies. Finally, some preliminary conclusions are discussed.

\section{Conflicts and institutions}

There is a growing debate on current models of peace maintenance in the aftermath of civil wars. According to Doyle and Sambanis (2000, p. 779), peacebuilding is 'an attempt, after peace has been negotiated or imposed, to address the sources of current hostility and build capacities for conflict resolution'. UN peacebuilding strategies have increasingly focused on institutionalization as a key component in solving conflicts. At the same time, 'neoliberal peacebuilding' has been marked by mounting criticism over the mainstream technical view of state-building and institutional reforms, which has been largely discarded because it failed to take into account cultural, social and historical needs (Groß \& Grimm, 2016; Mac Ginty, 2010).

Nevertheless, several authors believe that there is still some space for 'middle ground analyses' (Paris, 2004, p. 109) of the relationship between conflicts and institutions. On the whole, the current debate is affected by two main problems: the existing 'compartmentalization' of research and the limited attention devoted to an 'actor-oriented' perspective (i.e. the scarce interest towards the dynamic interaction among actors in post-conflict after power-sharing).

First, although some connections have occurred in the literature, the integration of different branches of literature has been extremely limited. Comparative politics, democratization, peacebuilding, civil war and crisis management studies rarely integrate their analyses and perspectives with the field of post-conflict research. According to Grimm and Weiffen, there has been an 'evident lack of dialogue' (2018, p. 263) between different strands of the literature, especially concerning the interaction between domestic and international actors.

Second, there is a growing need for systematic analyses that take into account what Zürcher (2018) calls the dynamic process of bargaining among strategic players in postconflict. Also, for this reason, we should better look at the dynamic relationship between types of conflicts and institutions. Especially dialectic long-term human interactions, which represent crucial aspects in determining the successes or failures of peacebuilding, deserve attention. ${ }^{4}$

There are manifold 'dilemmas of peace-building' (Jarstad \& Sisk, 2008, p. 1), from electoral design to state-building theory and practices in 'war-to-democracy transitions'. But power-sharing represents the most controversial dilemma. Do power-sharing mechanisms enable or hinder the transition of a divided society towards democracy? 
Different views emerge in the literature regarding the influence on peace and stability of distinguished institutional designs (Caspersen, 2004; Sisk, 2013; Strøm, Gates, Graham, \& Strand, 2015). According to consociationalism, power-sharing allows a better representation of all the important groups in a divided society (Lijphart, 1977, 2002). Power-sharing institutions are 'intended to provide each group with a guarantee that it will have a minimum level of representation within government' (Hoddie \& Hartzell, 2010, p. 9). Recent research has tried to 'disaggregate power-sharing', investigating its components, such as certain proportional electoral systems or as specific types of parliamentary systems (Cammet \& Malesky, 2012, p. 983).

Others have identified different analytical dimensions of power sharing, such as inclusive, dispersive and constraint power sharing (Strøm et al., 2015), assessing their different impact on democratic survival (Graham, Miller, \& Strøm, 2017). In fact, power-sharing can also affect democratization negatively by excluding moderate elites or freezing ethnic divisions through group representation. 'Centripetalism believes that the best way to manage democracy in a divided society is [...] to put in place institutional incentives for crossethnic behaviours to encourage accommodation between rival groups' (Reilly, 2010, pp. 288-289).

Several authors (Horowitz, 1985; Reilly, 2010) support integrative approaches to powersharing and centripetalism, which aim to reinforce the centre of a divided political spectrum through incentives for cooperation across ethnic lines. Binningsbo and Rustad (2012) state that power-sharing is not a positive factor per se, but that it depends on the type of institutional design and its implementation (e.g. resource distribution, land reforms, etc.). This 'flexibility' explains why the literature on the relationship between regime type and civil war recurrence has fostered growing attempts to disaggregate the concepts adopted in the empirical analyses, focusing on different types of institutional design (and their implementation).

Therefore, in line with the dynamic analysis of Graham et al. (2017), the paper offers a preliminary typology on institutions after power-sharing, moving away from compartmentalization and linking the literature on peacebuilding with civil wars, democratization and crisis management studies. The typology aims at systematizing and clarifying the abovementioned attempts to disaggregate key-concepts, going beyond a schematic division between 'stability' or 'political transformation' as main goals of peacebuilding. This, in turn, allows identifying an understudied area of research: the dynamic political confrontation among parties within parliaments in post-conflict societies. We focus specifically on post-war contexts because of the peculiar problems young democracies address in such contexts: the legacy of political violence, armed groups that become parties, third (international) actors. Therefore, along with the process of institutionalization of parties and party systems (Panebianco, 1988; Sartori, 1976), post-conflict democracies require that parties dismiss violence and mitigate ethically or religiously-based radicalization. Because of such problems the analysis of legislative interactions deserves specific attention.

\section{A typology}

The different contexts where several forms of civil war and social conflict take place to originate from diverse combinations of variables. By summarizing the vast literature on international security, peace research and civil wars, it is possible to identify several 
'frequent variables' that shape contemporary conflicts. These variables are: the content of the conflict, the number of conflicting groups and their relative strength, the territorial concentration (without a mixed population) or dispersion (with a diverse population, e.g. in Bosnia) of groups, the presence and collocation of significant natural resources (e.g. resource dispersion without centralized control, such as in Sierra Leone), institutional legacies (Sriram \& Zahar, 2009), the intensity and duration of conflicts (Kalyvas, 2006), third-party interventions (Mattes \& Savun, 2009) and past political and diplomatic agreements.

Institutional solutions have to fit into different war contexts and prove to be appropriate for different kinds of problems. There are three ideal types of 'context': a centre/(territorial or social) periphery conflict, where fundamental power resources are controlled by a political centre, a polycentric order where there is not a centralized control of power resources, and a fragmented context where fundamental resources are scattered. The various ways of arranging power-sharing can be put together in different combinations, adapting them to each situation. Therefore, in order to systematize the current debate, we outline an analytical partition of institutional solutions based on two general dimensions: procedures (modalities of implementation) and domains (fields in which provisions are implemented).

(A) Procedures. Institutional solutions are observable through a general parameter: goals. The literature has stressed two fundamental post-conflict goals. The first, which could be labelled as 'negative' because it deals with the reduction or removal of threats perceived by political players, concerns the management of the security dilemma. Generally, power-sharing provisions are related to this first goal, which seems mainly associated with the following features: short-term time horizon, ex ante solutions, the relevant role of third part engagement. Each solution can be considered as oriented towards the short, medium, or long term. Therefore, the timing and pace of the institutional design in the different phases of the post-war context are crucial. Power-sharing focuses on lowering the level of distrust that hinders the achievement of a commitment acceptable to the conflicting groups and, then, of a stable agreement among them.

The second 'positive' goal aims to transform political culture and improve state capacities. It looks more like a medium-/long-term objective and ex post solutions (left to free negotiation of political player) because it strives to improve the efficiency of political systems (especially responsiveness and accountability), and overcome the sources of conflict by lessening ideological polarization and the harshness of identity cleavages, and by promoting a larger sense of community.

(a) Domains. This category pertains to three parameters. The first domain regards politics, particularly the power allocation at the decision-making level, and concerns the distribution among political groups of functions and roles within institutions, such as parliaments, cabinets and local powers. The second domain regards public administrations and regards the allocation or regulation (e.g. removing the obstacles, de rule or de facto, that hinder equal access) of the positions within administrative structures, at both civilian and military level. The third concerns policies, specifically 
the agreements about the rules shaping contents and procedures of public policies. Contents are both distributive (regarding the allocation of social resources among individuals and groups) and regulative (on social and civil rights).

By combining the two above-mentioned criteria (goals and domains), we obtain an exploratory classification (Table 1) of the most important institutional solutions to conflicts.

The first classification, which includes most of the traditional power-sharing solutions, stems from the combination of the three domains with the 'negative' goals, which aim to lessen fear and insecurity. At the government level, for instance, we can find consociational arrangements based on ex ante (i.e. not depending on electoral outcomes) distribution of cabinet seats among political players (e.g. in Bosnia after Dayton). At the administrative level, we refer to the proportional allocation of positions within armed forces and bureaucracies to the different segments of societies (for instance, South Africa or Lebanon). Finally, at policies level, on the one hand, we can have solutions relying on an ex ante allocation of the main social (material and symbolic) resources, especially in countries rich of commodities (e.g. the 'Agreement on Wealth Sharing' between Sudan and South Sudan). On the other hand, indirectly, determined issues can be excluded - ex ante - from the political agenda (religious or specific economic issues for instances), or constrained by specific veto power assigned to the main political actors.

The second configuration is related to 'positive goals', aiming to favour, on one side, the political integration of deeply divided groups (especially by setting up inclusion mechanisms in nation-building) and, on the other side, to improve the efficiency and effectiveness of the political system, assuring responsiveness (e.g. the capacity to produce public goods and respond to the different populations' political claims). The parliamentary level involves the long-term interactions among parties and their ideological and strategic transformations linked to this continuous confrontation and compromise process, fostering nation-building. Reconciliation and cooperation can indeed reduce uncertainty among groups (e.g. Northern Ireland). The administrative level concerns all the choices that can improve the efficiency and accountability of the different branches of the state, favouring state-building (e.g. the reforms of judicial systems). Finally, the policy process had to be shaped in order to promote economic and social growth. We can find two different arrangements. In the first one, the range of choices is limited by some normative constraints (e.g. norms regulating the public budget). The second involves measures, even fostered by the international community, explicitly directed at favouring (e.g. through reforms or educational programmes) economic development and a less polarized political culture.

Table 1. Near here - Institutions and power-sharing.

\begin{tabular}{lll}
\hline $\begin{array}{l}\text { Goals } \\
\text { Domains }\end{array}$ & \multicolumn{1}{c}{ 'Negative goals' } & \multicolumn{1}{c}{ 'Positive goals' } \\
\hline $\begin{array}{c}\text { Decision- } \\
\text { making }\end{array}$ & $\begin{array}{c}\text { To enhance political inclusion and power-sharing } \\
\text { at the government level (regional and national } \\
\text { cabinets) }\end{array}$ & $\begin{array}{c}\text { To enhance political inclusion and power-sharing at } \\
\text { the legislative level (parliaments, parties and } \\
\text { party systems) }\end{array}$ \\
$\begin{array}{c}\text { Administration } \\
\text { To promote a proportional allocation of seats and } \\
\text { offices }\end{array}$ & $\begin{array}{c}\text { To increase the effectiveness and efficiency of } \\
\text { public services } \\
\text { To remove horizontal inequalities and the direct } \\
\text { negative effects of natural resources } \\
\text { negative effects of natural resources }\end{array}$ \\
\hline
\end{tabular}


The literature has devoted considerable attention to all the elements in the two configurations. With a relevant exception: the organized political confrontation among parties within parliaments. Empirical analysis demonstrates how access to state power (generally measured on the basis of influence over the executive, cabinet seats, etc.) is a pivotal factor relating to the risk of conflict and its duration, as 'discriminated groups are even more prone to experience violence than excluded ones' (Cederman, Gleditsch, \& Buhaug, 2013, p. 215). But parliament, as well as party development in legislative arenas, is seldom at the centre of the analyses that look at the formal and informal arrangements of junior partners in power-sharing regimes. However, power-sharing 'within the central executive' is not the only way that ethnic inclusion can be implemented. The analyses of inclusive power-sharing at the legislative level are generally limited to reserved seats, veto powers and electoral rules, underestimating the dynamic bargaining between political parties after elections. While most research has focused on civil society, a systematic examination of the implementation of ethnic inclusion in parliament is lacking.

Parliaments are often an environment in which a party's role and organization can be strengthened, along with the process of institutionalization. Within parliaments, parties negotiate on the allocation of the main resources among different segments of population, often inside specific and dedicated committees. This task encourages a growing specialization and structuring of parties, anchoring them to the needs of the more important social groups, and enhancing the connection between political institutions and society. Within these arenas 'catch-all parties' or multi-ethic and national parties, also because of specific electoral rules, may at times overcome parochial affiliations in favour of taking in a larger cross-section. In a long-term process, parliaments may foster the transformation of group attitudes, preferences and strategies, to better promote the easier institutionalization, and pragmatism of political forces, even affecting their identity.

The role of political parties might be relevant in the 'administrative domain' too. Parties, which are 'the central intermediate and intermediary structure between society and government' (Sartori, 1976, p. IX), are essential for modern democracy because they perform representative and institutional functions. Political parties have monitoring capacities, and they are able to articulate and channel political demands originating from society. 'As key agents of both political development and conflict management, political parties should play a critical role in post-conflict peacebuilding' (Reilly, 2013, p. 88). Parties can improve not only the state's ability to understand and respond to social needs but also the capability to persuade people to accept specific public policies, enhancing democratic effectiveness. Finally, the long-term interaction between parties within a parliamentary context also reveals the crucial symbolic dimension of the dynamic relationship among political actors in post-conflict societies.

In short, as shown by our typology, the literature should make an in-depth investigation of the role of political parties within parliaments in post-conflict societies.

\section{Political parties in post-conflict contexts: a growing (but still incomplete) literature}

Inclusive institutions reduce the fear of marginalization, increasing mutual confidence between rival groups. Repeated interactions 'among elites in a context of power-sharing 
may facilitate reciprocal trust' (Bunte \& Vinson, 2016, p. 61). ${ }^{5}$ But how is it possible to systematically assess the implementation of bargaining and the elites' intent to cooperate? How can we better understand the dynamic interactions between local political players, as well as their features, aims and interests? How can we examine the day-by-day process of confrontation, cooperation, accommodation and modernization of parties in post-conflict situations?

The analysis of political parties within parliaments after civil wars potentially allows an answer to those questions by investigating elite agendas and their concrete willingness to implement peace agreements. However, as stated by Ishiyama (2014, p. 427): 'for a long time there has been scant literature on party systems' development in places where civil wars have occurred'. Although the institutionalization of the party system (Panebianco, 1988) tends to be problematic in new democracies (e.g. low levels of legitimacy and weak roots in the society of political actors), political parties, especially 'national party politics' that can overcome divisions across ethnic lines, remain 'indispensable' for democratization. Indeed, political parties represent the link between people and state, aggregating and articulating interests. Peacebuilding literature has usually adopted Sartori's (1976) minimalist definition of political parties as any 'political group that presents at elections, and is capable of placing through elections, candidates for public office'.

This section, which provides an updated and critical review of a growing line of research on the development of political parties after civil wars, paves the way for building a potential research agenda on political parties in post-conflict societies. In fact, we identify the main gaps in current studies, revealing the absence of systematic analyses on the longterm dynamic interactions between parties in the legislative arena.

The analyses of political parties in post-conflict societies follow different analytical approaches. Generally, we can distinguish two perspectives. The first one tries to examine the link between institutional variables and process variables (in terms of choices and strategies of political actors). In this case, the behaviour of political parties is connected with the incentives structure modelled by specific political institutions (executive, parliament, electoral system, etc.). The second focuses on processes, aiming at explaining the aftermath of civil war and social conflicts on the basis of the contingent and various interactive strategies of parties.

However, studies that examine the impact of political institutions focus mainly on electoral system and executives, largely neglecting the role of legislatures. In addition, analyses that scrutinize the dynamic tactics and strategies of parties (e.g. rebel groups that become parties) often don't connect them to the constraints and opportunities of legislative assemblies. Moreover, such studies are mostly focused on electoral competition, overlooking other important phases, like the long-term inter-party interaction that takes place in parliaments. In sum, we can highlight five general paths of the existing literature on political parties in post-conflict societies.

First, an increasing body of research has focused on the transformation of rebel groups into political parties (Wittig, 2016), by examining the factors that influence their organizational transformation (Lyons, 2016) or their electoral success (Manning \& Smith, 2016, 2018), considering how the political career of former rebels varies (Gerdes, 2017) or whether the inclusion of those groups promotes a durable peace (Marshall \& Ishiyama, 2016). ${ }^{6}$ Most of such scholarship devoted specific attention to disarming and demobilization and to the role of the international community in peacebuilding efforts. 
However, as stated by Lyons (2016, pp. 1028), 'until recently, scholars of political parties paid relatively little attention to cases following civil war and the conflict resolution community said little about the roles played by post-conflict parties in promoting peacebuilding'. In conformity with Alfieri (2016, p. 235) 'while there is a growing literature on the transformations of armed groups into political parties as part of wider peace-building initiatives, the issue of how parties operate, organize and mobilize beyond the transitional phase is not studied enough'. If the political participation of former rebels in democratic process has been recently assessed (Manning, 2007; de Zeeuw, 2010), a cross-time analysis of their interactions, behaviours and rhetoric within political parties in legislative arena is still missing.

Second, other scholars have analysed parties and elections in post-war scenarios, focusing especially on the influence of electoral laws and party regulation on the nature of political parties (Bogaards, 2000). A peculiar attention has been devoted to proportional representation (PR) electoral system, due to its supposed ability to 'integrate groups' (Taylor, 2005, p. 455) and minorities, or to promote stability by fostering 'party discipline' (Cammet \& Malesky, 2012, p. 982) through closed-list PR. Parties and party leaders' strategies to secure a voter base and international support for political party development have also been examined (Manning, 2007). Moving beyond Eurocentrism, recent research has also explored the factors (e.g. colonial administration, periods of military rule, etc.) that shape party competition in Africa, Asia and Latin America (de Zeeuw, 2010).

However, the effective parliamentary attitudes of MPs after post-war elections (e.g. the supposed marginalized behaviour of MPs elected with reserved seats in the legislative arena) have been rarely scrutinized by longitudinal analyses. Moreover, the differences between electoral and parliamentary contexts are important also for the divergent incentives structure they produce. Indeed, electoral competition induces parties to differentiate each other, stressing the ambitious goals set by their propaganda. Within parliaments, instead, they are more easily encouraged to adopt strategies of cooperation and compromise (exploiting, for instance, the opportunities of logrolling and of the facilities linked to parliamentary committees).

A third path of the literature has scrutinized party formation and the regulation of parties in post conflict (Reilly \& Nordlund, 2008). Scholars have investigated 'formal elements' concerning parties and power-sharing agreements, such as the effects of veto-rights (Ram \& Strøm, 2014) and reserved seats to minorities (Reynolds, 2005). Nonetheless, studies on the specific parliamentary behaviours of the legislators in reserved seats are still lacking. Such research could also be helpful in explaining the 'tendency to split' (Hulsey, 2015, p. 521) of parties in ethnically divided societies before it occurs.

Four, an increasing interest emerged also regarding ethnic outbidding and party modernization strategies in contexts of peace processes. Indeed, several authors (GormleyHeenan \& MacGinty, 2008; Garry, 2014) have pointed out the capabilities of ethnonational parties to combine - depending on the issue - outbidding politics and ethnic tribune appeals with modernization strategies and pragmatic positions. Existing analyses mainly trace such combination by looking at the electoral competition, voting behaviour, or public debates. Yet, systematic research on the parliamentary debates over crucial issues is absent, despite the fact that legislative arenas would provide excellent sources to assess conciliatory or confrontational attitudes.

Five, current research on civil wars and peacebuilding has gradually adopted frame and narrative analyses on parties in post-conflict. Cederman et al. (2013) recently focused on the 
interactions between the state and the actors at intermediate levels of aggregation (such as ethnic groups and rebels), revealing the impact of grievances on civil wars and the role played by ethnic nationalism in fuelling conflicts. The authors examined the causal pathway in the process 'from inequalities to grievances', by looking at: group identification, intergroup comparison, the evaluation of injustice, and framing and blaming.

The interaction among parties in parliament allows all these elements to be studied from a different perspective, with specific attention devoted to 'framing'. Moreover, some authors have focused on the types of 'effective frames' adopted by 'successful outbidders' (Moore et al., 2014, p. 159) to exploit the fears of their communities while identifying strategies and opportunities for redressing these grievances. Others have examined the rhetoric of elites and the strategic use of religious (Bunte \& Vinson, 2016) or historical narratives (McGrattan, 2014) to mobilize the followers or to reframe the past after conflicts. Nonetheless, the above-mentioned studies have mainly investigated elites' frames and narratives concerning transitional justice or electoral rhetoric. But systematic content or discourse analyses of the speeches given by MPs of ethnonational parties in postconflict parliaments have seldom been provided.

In short, research that highlights the interaction between parties in post-conflict transition remains rare. Rather then focusing on electoral behaviours or basing qualitative research on 'simple observation' of attitudes and approaches of political parties, the literature lacks cross-time assessments of the day-by-day confrontation among elites in local and national parliaments in post-conflict divided societies.

We, therefore, believe that the emphasis on the behaviour of parties in parliament is important for at least two reasons. First, parliaments are the more suitable context where post-war parties debate and negotiate and where they can gradually change their political identity and their attitude towards political rivals. Second, parliamentary activities are a long-lasting political process in which parties are engaged, much longer than electoral competitions. Thus, neglecting this important, and often constitutive, aspect of the parties' political life would be a serious shortcoming.

Only by looking carefully at the wide range of activities of parties within parliament research can provide a detailed analysis of how local and national political actors frame grievances and security dilemmas, express political needs and demands, craft narratives and ideologies, socialize with other actors, foster accommodative attitudes, adapt recurrent patterns of behaviour, and reveal commitment to peace agreements.

Through the support of selected empirical examples, the next paragraph illustrates the ways through which a more systematic analysis of political parties in legislative arena could better address the dynamic process of 'inter-ethnic cooperation' in post-conflict societies.

The aim of the following section is to provide a 'research agenda' for further investigation. This is grounded in selected case studies that already include illustrative elements that can be scrutinized in order to look in more depth at post-conflict parliaments and party development.

\section{A research agenda on parties in post-civil wars parliaments}

How can a research agenda on parties, parliaments and party systems be structured? How and to what extent can the interactions among parties be concretely examined within parliaments after power-sharing agreements? 
In order to answer the above-mentioned questions, we develop a research agenda based on three crucial paths. The first concerns the strategic dimension of the intergroup party dynamics in legislative arenas. The second attaints at the symbolic level, more related to the ways through which parties frame grievances and craft narratives (and counter-narratives) on fundamental political issues. The last aspect is related to broader 'normative' and methodological issues, which also helps in understanding the reasons behind the limited attention devoted by the literature on party development within legislative arenas. After having examined these three paths though empirical examples the paper advances potential hypotheses on parties in post-conflict parliaments.

The first path of the agenda attaints at the intergroup party dynamics in parliaments, focusing on negotiations around power and interests.

A more detailed examination of legislative 'intergroup party dynamics' illustrates the ways in which political players implement power-sharing, by revealing the accommodation of grievances, the effective commitment of actors and the attempt to improve information, therefore increasing 'reciprocity' among groups. Analysis of confrontation between parties in legislative contexts would lead to a better understanding of the ways through which actors try to accommodate grievances beyond short-term interactions by expressing their needs and interests in the negotiation. Even though scholars and practitioners have addressed the problems of how to guarantee effective party commitment after peace agreements (for example, by stressing the vital role played by third parties and the need to increase the stakes in a shared future), limited research has been made on the tangible 'institutional commitment' of political parties. Thus, parliament represents an excellent item of investigation for assessing the 'credibility of commitment' after power-sharing (Hartzell \& Hoddie, 2003), illustrating the participation and involvement of key players in the relevant political issues that require legislative activities. Moreover, parliamentary procedures are fundamental because they 'set the framework' for bargaining among actors, hence regulating the legislative implementation of powersharing.

Legislative assemblies highlight formal and informal exchange relations among parties and the ways through which actors seek to obtain information about each other, which is crucial for understanding (and potentially even overcoming) the security dilemma in postconflict societies. Indeed, boosting the counterpart's level of information may lead to an increase in reciprocity and extended trust.

The post-conflict legislative arenas in Bosnia and Northern Ireland provide useful examples on the ways through which it is possible to investigate in-depth inter-ethnic interactions. Hulsey (2015) has illustrated the interactions between Croat and Bosniak parties (HDZ - Croatian Democratic Union, and SDA - Party for Democratic Action), which had formed ruling coalitions and worked together. ${ }^{7}$ Despite consistent relevant obstacles (such as a market of voters deeply segmented along ethnic lines), inter-ethnic cooperation exists, also due to the power-sharing mechanisms imposed by the Dayton agreement (Caspersen, 2004).

Recently, attention has been devoted also to the cases of multi-ethnic parties such as the SDP - Social Democratic Party and Naša Stranka, a party established with an 'explicit anti-nationalist platform' (Touquet, 2011, p. 456). But while the literature has mainly investigated the phase(s) of political mobilization, the ways through which these parties behave within legislative arenas (and how they have affected the 'rules of the debate' set by ethnic 
parties) have attracted scarce interest. As recognized by the leader of Naša Stranka, Kojović, the party 'made some mistake', 8 collecting useful lessons learnt. By examining the relationship with other parties in parliaments we can better understand how these views and perceptions have been influenced.

The day-by-day analysis of the parliament of the Federation would illustrate the dynamic interactions as well as the changes occurred within 'wartime parties' (in terms of programmes, reforms, attitudes, etc.), giving additional details also on the reasons behind the collapse of previous ruling coalitions (as in 2015), as well as on the different needs expressed by the elites across time. For instance, the examination of legislative debates in municipalities could reveal the cross-time interactions between parties of some communities (e.g. SDA and SBiH - Party for Bosnia and Herzegovina), their changes, and the degree of linkage with multi-ethnic parties.

Moreover, rather than focusing only on the electoral competition within crucial 'monoethnic subunits' (Hulsey \& Stjepanovic, 2017, p. 57), we should look at the dynamic interactions that occur among parties of the same community at the legislative level. It is worth noticing how the unity of these parties is generally oversimplified, as the different positions adopted by Bosnian and Croat parties during the constitutional negotiations in 2006, well illustrated. ${ }^{9}$

Thus, the analysis of (national and local) legislative debates could provide a detailed account of the priorities and strategies adopted by wartime (and post-war) parties for inter-ethnic cooperation and competition. On the other hand, these legislative debates could also shed light on the split occurred within parties, such as in the SDP. As said previously, more than one party competes for Bosniak, Serb and Croat votes, illustrating a growing diversification of the party system. ${ }^{10}$

The parliamentary debates concern the national, ${ }^{11}$ municipal and cantonal dimensions, where a cross-ethnic majority is technically requested and, therefore, cooperation is more frequent. Caspersen has examined the inter-ethnic cooperation in heterogeneous municipalities, illustrating the different alliances built across time in Bosnia despite mutual vetoes and emphasizing the increasing number of laws adopted by parliaments in recent years. Indeed, by collecting data on laws and reforms that crosses the ethnic lines, we can better assess a possible greater pragmatism of wartime parties (Caspersen, 2004, p. 580).

Despite the fact that most decision-making competencies lie with the entities, other policies (such as transportation, environment, foreign and defense policy) 'cross entity lines', requiring complex negotiations, involving parties in parliaments (Keil \& Perry, 2015). An example of a successful reform adopted in those policy areas was the integration of armed forces in 2006.

On the whole, legislative arenas represent ideal sources to examine such processes of accommodation among parties in ethnically divided societies, illustrating the voting behaviour in commissions and in general assemblies. As shown by the literature, power-sharing mechanisms have the potential to reinforce existing divisions, thanks to the emergence of leaders of nationalist parties who engage in ethnic outbidding, appealing to nationalism and thus cementing ethnic representation in the long run.

However, as stated above, recent studies (Garry, 2014) have illustrated the combination of ethnic outbidding and modernization of post-war parties. The analysis of legislative debates allows for an understanding of this mechanism, highlighting the pragmatism and the 'conciliatory positions' of former 'extreme' ethnonational parties. The legislative 
behaviour of Sinn Fein and Democratic Unionist Party - DUC (which agree to share power after 2007 in Northern Ireland ${ }^{12}$ ) well exemplifies such a process of 'moderate attitudes' within parliaments, 'moving away from narrow platforms' based on ethnic membership (Gormley-Heenan \& MacGinty, 2008). These parties adopted (simultaneously) pragmatic approaches on resources and intransigent views on identities, thanks to ethnic tribune appeals. In Northern Ireland the hard-line parties coordinated policies, moving towards the centre of the political spectrum.

On the whole, such intentions of 'de-nationalizing politics' (Hulsey, 2010) could be better assessed through a systematic examination of party development within parliaments, rather than just focusing on executives or on elections. For instance, legislative debates on issues such as political violence (e.g. condemnations of murders after 2007 against destabilization) could reveal different approaches and strategies over time, towards a 'normalisation of politics' (Garry, 2009, p. 465) in Northern Ireland. Rather than focus on voters or opinion polls, the decisions adopted in the legislative arenas (e.g. on controversial issues such as the Welfare Reform Bill 2015), as well as the rhetoric crafted to justify them, could better identify examples of pragmatism, moderation or ethno-nationalism.

A comparison of the internal evolution that occurred within Bosnian wartime parties (especially the HDZ, and the Serbian Democratic Party - SDS) has been made only before and after electoral campaigns, without examining in details the long-term transformation of their legislative behaviours, at entity and cantonal levels, assessing for example the variation from mono-ethnic to 'mixed-ethnic cantons' (Hulsey, 2010, p. 1143).

Also, the changes occurred in party regulations, especially concerning party financing, represent overestimated sources of information on party systems development. Ishiyama and Batta (2011, p. 369) have investigated the case of the Communist Party of Nepal (CPN) and the process of accommodation with other political actors, identifying the evolution of strategies, internal struggles, leadership and organization through official documents and debates. The transformation of 'revolutionary attitudes' within a specific 'ideological background' (e.g. concerning land reforms, social services, the future of monarchy, etc.) could be traced by looking at public speeches within legislative arenas. A detailed account of the dynamic parliamentary interactions among post-war parties could reveal the specific issues where such conciliatory attitudes emerge more frequently.

Finally, by looking at legislative assemblies, it is possible to better monitor how former rebels gradually become 'dominant parties' in the political scenario, as well as the concrete attempts made by the opposition to balance an increasing influence on national legislation. In that sense, the parliamentary debates between the Mozambique Liberation Front (FRELIMO) and the Mozambican National Resistance (RENAMO) represent an excellent example that should be investigated further (Manning, 2007).

In sum, several plausible hypotheses can be developed regarding the intergroup party dynamics in post-conflicts parliaments. First, one can expect that the more shared votes and attitudes emerge in the day-by-day interactions at legislative levels, the more parties will draw pragmatic and moderate platforms in further elections, moving gradually away from narrow programmes based solely on ethnic membership. In other words, a repeated legislative interaction among parties on relevant political issues could enhance their 'institutional commitment', fostering accommodation and reciprocity. This hypothesis speaks well also with recent research on how political experience affects performance by former-rebel parties (Manning and Smith 2018). 
Second, and relatedly, only 'powerful post-war parliaments' will create incentives for parties to be actively engaged within the legislative process, promoting compromises and contrasting potential zero-sum games at the institutional level. On the opposite, weak parliaments with limited oversight on the executives and on the management of public resources (e.g. in contexts where patronage networks are extremely active) will lead parties to focus almost exclusively on symbolic issues, mainly promoting ethnic tribune appeals.

The second path of the agenda focuses on the symbolic dimension.

\section{How do political actors frame grievances and post-war security dilemmas?}

The analysis of the interactions between parties in parliaments helps in identifying narratives, counter-narratives and frames. As illustrated by recent studies on civil wars (Costalli \& Ruggeri, 2015), emotions and ideologies play a very relevant role in the process that leads from horizontal inequalities to war through the formation of grievances and collective action. Framing the material conditions, as well as crafting narratives based on anger and indignation, appears crucial in this sense. Framing specific or general demands represent not only symbolic acts but rather it helps in defining (and therefore in defending) those interests. The 'emotional reactions' to horizontal inequalities can be better grasped by looking at the parliamentary confrontation among (and within) groups. Parliament is an ideal arena for examining the confrontation between 'strategic narratives' based on cooperative or confrontational 'plots' (e.g. aiming at increasing cooperation or rather hindering any accommodation) on past conflicts. As illustrated by Gromes, 'intra-party competition and inter-party contestation offer incentives to inflame hatred and fear' $(2009$, p. 93).

The cases of Bosnia, Cyprus and Northern Ireland are extremely useful to understand the role played by historical narratives and the ways through which political parties (re)framed the past in ethnically divided societies. ${ }^{13}$ Moore et al. (2014) have stressed the effective 'identity based-frames' adopted by outbidders for mobilizing their communities. The legislative debates would illustrate in details diagnosis and prognosis frames (those identifying sources and solutions to problems) as well as the overall narrative dominance (the balance between narratives and counter-narratives) concerning 'justice', 'true' and 'memory wars'.

The evolution of frames and narratives crafted in the parliamentary speeches before national and municipal assemblies on war crime issues in Bosnia or on the sectarian violence during (and after) the 'troubles' in Northern Ireland represent maybe the most relevant examples to illustrate the impact of significant political discourse in divided societies. The transformation of the party's 'wartime image' could start within the parliament, promoting more 'institutional' political messages, as attempted by the SDS or by the PDK (Democratic Party of Kosovo) in the Balkans.

Basta (2016, p. 944) has investigated the discursive battlefield on institutional change in Bosnia, revealing different narratives adopted by Bosniak, Serb and Croat parties: 'formal institutions may also be symbols that embody narratives about groups identity'. But one would go further, assessing the 'narrative dominance' between ethnic (or post-ethnic) narratives and counter-narratives among parties within parliaments. The ways through which leaders and MPs in parliaments have articulated their narratives before other actors, affecting the transformation of the whole political discourse, still needs to be investigated 
in detail. For example, the consistency (or the lack thereof) between frames adopted by elites in parliaments and electoral manifestoes elaborated by parties merits attention.

A promising approach has been adopted by Bunte and Vinson (2016), who have analysed local and informal power-sharing institutions, highlighting the rhetoric of elites in Nigerian districts. One of the main findings is that elites in districts with power-sharing agreements use more cooperative rhetoric and symbolic behaviour towards other religious groups. Through parliamentary analysis, we can deeply understand the political demands expressed by parties in the bargaining phases, and focus on power and local levels of confrontation.

Still few studies have considered the ways through which political entrepreneurs frame specific emotions and openly express systems of beliefs. The 'symbolic capital' of the postwar elites has rarely been assessed within a legislative arena, while considerable interest has been devoted towards the social and political capital of former rebels. Attitudes, approaches and feelings (e.g. suspicion, trust) are regularly articulated within an assembly, where 'hostile leaders' come to cooperate in the very first phases of transitional powersharing agreements. Connecting communication studies based on framing, strategic narratives literature and discourse analysis with civil war research and peacebuilding scholarship may help provide a detailed picture of elites' beliefs and political cultures, which are a crucial dimension in the dynamic interactions among political actors in post-conflict institutional transition.

In sum, we can suppose that high level of interaction among parties within legislative contexts featured by power-sharing agreements will be related with strategic narratives based on cooperative 'plots', with shared frames, especially on crucial symbolic issues, like memory wars. According to such hypothesis, the constant legislative interaction and the institutional cooperation on selected issues within parliaments - could shape similar 'core frames' of different strategic narratives adopted by post-war parties.

Finally, the third path of the agenda concern methodological issues on $p$

arties and, parliaments in peacebuilding research and conflict studies.

The analysis of political parties in post-conflict situations would provide a significant contribution to peace-building processes. As stressed by Carothers (2006), political parties are the weakest link in many democratic transitions around the world. In addition, the parliamentary role of parties, a type of party assistance, has seldom been at the centre of projects and programmes of democratic assistance, which are generally focused on electoral assistance. As pointed out by Wolf, 'it is futile to think about power in democracy promotion without paying attention to the local, trans - and international power relations' (2015, p. 230). Identifying the crucial domestic actors below leaders, and distinguishing between moderates and extremists, is a very hard task for peacebuilding operations because factional divisions and spoilers represent considerable obstacles in developing peace (Collier, Hoeffler, \& Rohne, 2006). For this reason, 'there is a need to identify strategies that discourage the emergence of those who oppose the settlement' (Hoddie \& Hartzell, 2010, p. 5). In order to better gauge these strategies, third-party interventions should increase their level of knowledge on the demands and patterns expressed by the local elites (Fortna, 2004).

Thus, analysis of the initial bargaining in local assemblies or parliaments could also have a normative value in fostering knowledge and information on those who are in charge of promoting peace and stability, and better prevent and contrast the moves by spoilers. 
However, to study the 'micro narratives' of political entrepreneurs in a conflict-prone or post-conflict scenario methodologically it is necessary to adopt a 'local perception'. In fact, qualitative approaches that aim to investigate the frames and narratives of political elites in a legislative arena should be based on a careful cultural understanding of the object of the analysis. For instance, some of the most common techniques adopted for examining legislative debates (e.g. content and discourse analysis) necessitate knowledge of the local language/s. In other words, a growing scientific involvement of scholars from the countries that are under investigation is required. As explicitly recognized by Bunte and Vinsom (2016, p. 55), who have assessed the number of 'cooperative and moderating statements by elites' in Nigeria, it is problematic to rely on 'sources that systematically codes types of statements' in districts.

However, at least at the national level, there are websites of post-war parliaments that provide the possibility to investigate in detail the repeated legislative interactions among parties, their political messages and the existence of confrontational or cooperative rhetoric. $^{14}$

\section{Conclusions}

The aim of the paper is to provide a research agenda on political parties within parliaments after civil wars, also advancing possible hypotheses that can be tested in farther studies. Despite a growing interest, there is still 'a gap in knowledge about post-war party development' (de Zeeuw 2010, p. 1193).

Analysis of parties in the national and local assemblies allows an examination of the ways in which parties express political demands, while clarifying the dynamic interactions among factions, parties, elites, as well as their features, role and commitments, which are also crucial to better calibrate power-sharing solutions in peacebuilding.

As suggested by recent literature (Belloni, 2012; Groß, 2018), the current research should devote more attention to the dynamic interaction between international agents and networks and local actors. Rather than focusing on the technicalities of liberal peacebuilding or adopting a 'romantic' view of the local actors, we shed light on a potential middle ground for analysis, illustrating how the dialectic political processes within national and regional legislative arenas deserve greater attention to understand post-conflict divided societies. Following recent studies on emotions and ideologies, the analysis of long-term inter-party relationships in the post-war phase may also demonstrate how political actors frame grievances, security dilemmas and the 'narrative dominance' of the conflict. Finally, adopting a 'local turn' in terms of methods (e.g. discourse analysis undertaken by local scholars) would allow acquiring a more comprehensive picture of the societies under investigation.

Further studies could investigate in detail how and to what extent different levels of institutionalization - as well as 'strength' - of parliaments, affect the system of incentives for parties in fostering their organization and their propensities to compromise. Additional analyses could better evaluate the effects of shared votes and attitudes within assemblies, assessing if 'strong parliaments' (with a primary role in the allocation of social resources) are suitable in facilitating the evolution of parties in post-conflict society.

Rather than focusing on formal aspects such as forms of government or constitutions, further analyses should examine the effective legislative powers (beyond the differences 
among parliamentary, presidential or semi-presidential systems) of post-war parliaments and the consequential development of political parties.

\section{Notes}

1. For an exception see Reilly (2013).

2. Recent exceptions are: Moore et al. (2014) and Bunte and Vinson (2016).

3. For an updated review see Garry (2014).

4. For instance, there aren't studies that 'relate power-sharing to democratic survival dynamically'. Graham et al. (2017, p. 687).

5. While the peace-building literature has generally examined elites at the government level, the paper focuses on the political elites in legislative assemblies. On domestic elites as neglected (and contested) concept see Grimm and Weiffen (2018). On central and secondary elite and peacebuilding see Zürcher (2018).

6. Marshall and Ishiyama investigated the long-term inclusion of former-rebel groups by looking at the proportion of seats held during the legislature. However, they do not provide detailed analyses on the tangible interactions between former-rebel groups in the legislative context.

7. See, for instance: 'Parties Start New Coalition Talks in Bosnia's Federation', available at http:// www.balkaninsight.com/en/article/talks-start-on-new-ruling-coalition-in-bosnia-sfederation\#sthash.9rxa62f2.dpuf.

8. Quoted in Touquet (2011, p. 458).

9. SDA supported the initiative while SBiH opposed it. Also the HDZ and the HDZ 1990 voted in different ways (Basta, 2016, p. 956).

10. In Bosnia there are nearly ' 200 parties competing in national, regional, and local elections' (Hulsey \& Stjepanovic, 2017, p. 43).

11. The lower chamber of the Bosnian assembly is elected according to a proportional system. Ethnicity plays a different role according to the mono-ethnic or multi-ethnic nature of different national or local institutions.

12. On consociationalism and Northern Ireland see: McGarry and O'Leary (2006).

13. The 'state-sponsored denial' of the genocide in Srebrenica is a relevant example (McGrattan, 2014).

14. For instance, the minutes of the debates in Sierra Leone are available also in English. See http://www.parliament.gov.sl. See also recent projects on parliaments and civil society such as: http://parliaments4people.com/projects/

\section{Acknowledgements}

A preliminary version of the paper has been presented at the Workshop 'Conflicts \& Institutions' (Genoa, 16-17 June 2016) and at the 2016 ECPR Conference (Prague). The authors wish to thank L.-E. Cederman, S. Costalli, K. Bakke, H. Hegre, F. N. Moro, A. Ruggeri, and all the panellists for their useful comments.

\section{Disclosure statement}

No potential conflict of interest was reported by the authors.

\section{Notes on contributors}

Giampiero Cama is Professor of Political Science in the DISPO - Department of Political Science at the University of Genoa.

Fabrizio Coticchia is Assistant Professor of Political Science in the DISPO - Department of Political Science at the University of Genoa. fabrizo.coticchia@unige.it 


\section{References}

Alfieri, V. (2016). Political parties and citizen political involvement in post-conflict Burundi: Between democratic claims and authoritarian tendencies. Civil Wars, 18(2), 234-253.

Basta, K. (2016). Imagined institutions: The symbolic power of formal rules in Bosnia and Herzegovina. Slavic Review, 75(4), 944-969.

Belloni, R. (2012). Hybrid peace governance: Its emergence and significance. Global Governance, 18 (1), 21-38.

Binningsbo, H. M., \& Rustad, S. A. (2012). A price worth fighting for? Natural resources and conflict recurrence. Journal of Peace Research, 49(4), 531-546.

Bogaards, M. (2000). The uneasy relationship between empirical and normative types in consociational theory. Journal of Theoretical Politics, 12(4), 395-423.

Bunk, B., (2018). The dynamics of donor and domestic elite interaction in Mozambique: Formal decentralisation and informal power structures. Conflict, Security \& Development, 18(4), 321-346.

Bunte, J., \& Vinson, L. T. (2016). Local power-sharing institutions and Interreligious violence in Nigeria. Journal of Peace Research, 53(1), 49-65.

Cammet, M., \& Malesky, E. (2012). Power sharing in postconflict societies. Journal of Conflict Resolution, 56(2), 982-1016.

Carothers, T. (2006). Confronting the weakest link: Aiding political parties in new democracies. Washington: Carnegie.

Caspersen, N. (2004). Good fences make good neighbours? A comparison of conflict-regulation strategies in postwar Bosnia. Journal of Peace Research, 41(5), 569-588.

Cederman, L.-E., Gleditsch, K. S., \& Buhaug, H. (2013). Inequality, grievances and civil war. Cambridge: Cambridge University Press.

Collier, P., Hoeffler, A., \& Rohne, D. (2006). Beyond greed and grievance: Feasibility and civil War. CSAE WPS/2006-10. Retrieved from https://www.csae.ox.ac.uk/materials/papers/2006-10text.pdf

Costalli, S., \& Ruggeri, A. (2015). Indignation, Ideologies, and armed mobilization, Italy, 1943-1945. International Security, 40(2), 119-157.

Chandler, D. (2004). The responsibility to protect? Imposing the Liberal Peace. International Peacekeeping, 11(1), 59-81.

de Zeeuw, J. (2010). 'Sons of war': Parties and party systems in post-war El Salvador and Cambodia. Democratization, 17(6), 1176-1201.

Doyle, M. W., \& Sambanis, N. (2000). International peacebuilding: A theoretical and quantitative analysis. The American Political Science Review, 94(4), 779-801.

Fortna, V. P. (2004). Does peacekeeping keep peace? International intervention and the duration of peace after civil war. International Studies Quarterly, 48(2), 269-292.

Garry, J. (2009). Consociationalism and its critics: Evidence from the historic Northern Ireland assembly election 2007. Electoral Studies, 28(3), 458-466.

Garry, J. (2014). Potentially voting across the divide in deeply divided places: Ethnic catch-all voting in consociational Northern Ireland. Political Studies, 62(1), 2-19.

Gerdes, F. (2017). Exit from war: The transformation of rebels into post-war power elites. Security Dialogue, 48(2), 168-184.

Gormley-Heenan, C., \& MacGinty, R. (2008). Ethnic outbidding and party modernization: Understanding the Democratic Unionist Party's electoral success in the post-agreement environment. Ethnopolitics, 7(1), 43-61.

Graham, B., Miller, M. K., \& Strøm, K. W. (2017). Safeguarding democracy: Powersharing and democratic survival. American Political Science Review, 111(4), 686-704.

Grimm, S., \& Weiffen, B., (2018). Domestic elites and external actors in post-conflict democratisation: Mapping interactions and their impact. Conflict, Security \&amp; Development, 18(4), 257-282.

Gromes, T., (2009). A case study in 'institutionalisation before liberalisation': Lessons from Bosnia and Herzegovina. Journal of Intervention and Statebuilding, 1 (3), 93-114.

Groß, L., \& Grimm, S. (2016). Conflicts of preferences and domestic constraints: Understanding reform failure in liberal state-building and democracy promotion. Contemporary Politics, 22(2), 125-143. 
Groß, L., (2018). Lean models, complex realities: Elite interactions in postconflict democratisation at the local level. Conflict, Security \& Development, 18(4), 301-319.

Hartzell, C. A., (1999). Explaining the stability of negotiated settlements to intrastate wars. Journal of Conflict Resolution, 43(1), 3-22.

Hartzell, C. A., \& Hoddie, M. (2003). Institutionalizing peace: Power sharing and post-civil war conflict management. American Journal of Political Science, 47(2), 318-332.

Hensell, S., \& Gerdes, F., (2012). Elites and international actors in post-war societies: The limits of intervention. International Peacekeeping, 19(2), 154-169.

Hoddie, M., \& Hartzell, C. A. (2010). Strengthening peace in post-civil war states. Transforming spoilers into stakeholders. Chicago: Chicago University Press.

Horowitz, D. (1985). Ethnic groups in conflict. Berkeley: University of California Press.

Hulsey, J. W., \& Stjepanovic, D. (2017). Bosnia and Herzegovina: An archetical example of an ethnocracy. In A. H. Schakel (Ed.), Regional and national elections in Eastern Europe (pp. 35-58). London: Palgrave.

Hulsey, J. W. (2010). Why did they vote for those guys again? Challenges and contradictions in the promotion of political moderation in post-war Bosnia and Herzegovina. Democratization, 17(6), $1132-1152$.

Hulsey, J. W. (2015). Electoral accountability in Bosnia and Herzegovina under the Dayton framework agreement. International Peacekeeping, 22(5), 511-525.

Ishiyama, J. (2014). Civil wars and party systems. Social Science Quarterly, 95(2), 425-447.

Ishiyama, J., \& Batta, A. (2011). Swords into plowshares: The organizational transformation of rebel groups into political parties. Communist and Post-Communist Studies, 44, 369-379.

Jarstad, A. K., \& Sisk, T. D. (2008). From war to democracy. Dilemmas of peacebuilding. Cambridge: Cambridge University Press.

Kalyvas, S. (2006). The logic of violence in civil war. Cambridge: Cambridge University Press.

Keil, S., \& Perry, V. (2015). Back to square one? An analysis of the, 2014. General elections in Bosnia and Herzegovina. Electoral Studies, 38, 82-87.

Kumar, K., \& de Zeeuw, J. (2008). International support for political parties in war-torn societies. In B. Reilly \& P. Nordlund (Eds.), Political parties in conflict-prone societies: Regulation, engineering and democratic development (pp. 261-285). Tokyo: United Nations University Press.

Lijphart, A. (1977). Democracy in plural societies: A comparative exploration. New Haven: Yale University Press.

Lijphart, A. (2002). The wave of power-sharing democracy. In A. Reynolds (Ed.), The architecture of democracy: Constitutional design, conflict management, and democracy (pp. 37-54). Oxford: Oxford University Press.

Lyons, T. (2016). From victorious rebels to strong authoritarian parties: Prospects for post-war democratization. Democratization, 23(6), 1026-1041.

Mac Ginty, R. (2010). Hybrid peace: The interaction between top-down and bottom-up peace. Security Dialogue, 41(4), 391-412.

Manning, C. (2007). Party-building on the Heels of War: El Salvador, Bosnia, Kosovo and Mozambique. Democratization, 14(2), 253-272.

Manning, C., \& Smith, I. (2016). Political party formation by former armed opposition groups after civil war. Democratization, 23(6), 972-989.

Manning C., \& Smith, I. (2018), Electoral performance by post-rebel parties. Government and Opposition. Advance online publication. doi:10.1017/gov.2018.34

McGarry, J., \& O'Leary, B. (2006). Consociational theory, Northern Ireland's conflict, and its agreement 2. What critics of consociation can learn from Northern Ireland. Government and Opposition, 41(2), 249-277.

McGrattan, C. (2014). Policing politics: Framing the past in post-conflict divided societies. Democratization, 21(3), 389-410.

Marshall, M. C., \& Ishiyama, J. (2016). Does political inclusion of rebel parties promote peace after civil conflict?. Democratization, 23(6), 1009-1025.

Mattes, M., \& Savun, B. (2009). Fostering peace after civil War: Commitment problems and agreement design. International Studies Quarterly, 53(3), 737-759. 
Moore, G., Loizides, N., Sandal, N. A., \& Lordos, A. (2014). Winning peace frames: Intra-ethnic outbidding in Northern Ireland and Cyprus. West European Politics, 37(1), 159-181.

Newmann, E., Paris, R., \& Richmond, O. P. (2009). New perspectives on liberal peacebuilding. Tokyo: UNU Press.

Panebianco, A. (1988). Political parties: Organization and power. Cambridge: Cambridge University Press.

Paris, R. (2004). At war's end: Building peace after civil conflict. Cambridge: Cambridge University Press.

Ram, M., \& Strøm, K. W. (2014). Mutual veto and power-sharing. International Area Studies Review, 17 (4), 343-358.

Reilly, B., \& Nordlund, P. (2008). Political parties in conflict-prone societies: Regulation, engineering and democratic development. Tokyo: United Nations University Press.

Reilly, B. (2010). Centripetalism. In K. Cordell \& S. Wolf (Eds.), The Routledge Handbook of ethnic conflict (pp. 288-299). London: Routledge.

Reilly, B. (2013). Political parties and post-conflict peacebuilding. Civil Wars, 15(1), 88-104.

Reynolds, A. (2005). Reserved seats in national legislatures: A research note. Legislative Studies Quarterly, 30(2), 301-310.

Sartori, G. (1976). Parties and party system: A framework for analysis. Cambridge: Cambridge University Press.

Sisk, T. D. (2013). Power sharing in civil war: Puzzles of peacemaking and peacebuilding. Civil Wars, 15 (1), 7-20.

Spears, I. S. (2000). Understanding inclusive peace agreements in Africa: The problems of sharing power. Third World Quarterly, 21(1), 105-118.

Strøm, K. W., Gates, S., Graham, B. A. T., \& Strand, H. (2015). Inclusion, dispersion, and constraint: Powersharing in the world's states, 1975-2010. British Journal of Political Science, 47(1), 65-185.

Sriram, C. L., \& Zahar, M. (2009). The perils of power-sharing: Africa and beyond. Africa Spectrum, 44(3), $11-39$.

Taylor, A. (2005). Electoral systems and the promotion of 'consociationalism' in a multi-ethnic society. The Kosovo assembly elections of November 2001. Electoral Studies, 24, 435-463.

Touquet, H. (2011). Multi-ethnic parties in Bosnia-Herzegovina: Naša Stranka and the Paradoxes of Postethnic policies. Studies in Ethnicity and Nationalism, 11(3), 451-467.

Wittig, K. (2016). Politics in the shadow of the gun: Revisiting the literature on 'rebel-to-party transformations' through the case of Burundi. Civil Wars, 18(2), 137-159.

Wolf, J. (2015). Power in democracy promotion. Alternatives: Global, Local, Political, 40(3-4), 219-236.

Zürcher, C. (2018). A theory of democratisation through peace-building. Conflict, Security \& Development, 18(4), 283-299. 